\title{
PERSEPSI KONSUMEN TERHADAP PEMASARAN DIGITAL PRODUK PERIKANAN DI DAERAH KHUSUS IBUKOTA JAKARTA
}

\author{
Consumer Perception on Digital Marketing of Fishery Products in Jakarta \\ Oleh: \\ Retno Muninggar ${ }^{1 *}$, Helmi Aulia ${ }^{2}$ \\ ${ }^{1}$ Departemen Pemanfaatan Sumberdaya Perikanan, FPIK IPB \\ ${ }^{2}$ Program Studi Teknologi dan Manajemen Perikanan Tangkap, \\ FPIK, IPB \\ ${ }^{*}$ Korespondensi penulis: muninggar@apps.ipb.ac.id
}

\begin{abstract}
ABSTRAK
Persepsi dan perilaku konsumen terhadap pemasaran digital hasil perikanan merupakan aspek yang penting untuk menentukan strategi pemasaran dan segmentasi pasar. Keputusan akhir pembelian produk perikanan dipengaruhi oleh berbagai faktor, diantaranya persepsi, karakteristik, dan perilaku konsumen. Permasalahan penelitian adalah belum adanya informasi yang lengkap terkait perilaku dan persepsi konsumen terhadap pemasaran digital produk perikanan di DKI Jakarta. Tujuan penelitian adalah mengidentifikasi perilaku konsumen, serta mengukur persepsi konsumen terhadap kinerja pemasaran digital produk perikanan. Pendekatan penelitian dilakukan melalui studi kasus dan menggunakan metode pengumpulan data accidental sampling. Data dianalisis menggunakan metode important performance analysis (IPA) dan customer satisfaction index (CSI). Hasil penelitian menunjukkan bahwa perilaku konsumen dalam pemasaran digital produk perikanan adalah sebagai berikut: konsumen membeli produk perikanan melalui pemasaran digital dengan alasan praktis $(60 \%)$, sumber informasi pembelian dari media sosial (43\%), konsumen memperhatikan tingkat kualitas (46\%), konsumen membeli rata-rata 1-3 $\mathrm{kg}$ produk perikanan (53\%) dan konsumen melakukan pembelian kembali (89\%). Persepsi konsumen terhadap keseluruhan atribut pemasaran digital hasil perikanan adalah puas (67\%), dengan prioritas utama peningkatan kinerja terletak pada atribut harga dan kualitas hasil perikanan dari pemasaran digital.
\end{abstract}

Kata kunci: konsumen, pemasaran digital, persepsi, perilaku, produk perikanan

\begin{abstract}
Perceptions and consumer behavior towards digital marketing of fishery products are important aspects to determine marketing strategy and market segmentation. Final decision to purchase fishery products is influenced by various factors, including perceptions, characteristics, and consumer behavior. The research problem is lack of information about characteristics, behavior and consumer perceptions of digital marketing of fishery products in DKI Jakarta. Objective of the study was to identify consumer behavior, as well as to measure consumer perceptions of digital marketing performance of fishery products. Research was conducted with case study approach and used accidental sampling data collection method. Data were analyzed using important performance analysis (IPA) and customer satisfaction index (CSI) methods. Results showed that consumer behavior in digital marketing of fisheries products: consumers get fisheries products through digital marketing for practical reasons (60\%), sources of purchasing information from social media (43\%), consumers pay attention to quality levels (46\%), consumers purchase an average of $1-3 \mathrm{~kg}$ of fishery products (53\%) and consumers make repeat purchases (89\%). Consumer perceptions of overall attributes of fishery products digital marketing are satisfied (67\%), price and quality attributes of fishery products are main priority of improving digital marketing performance.
\end{abstract}

Key words: consumer, digital marketing, perception, behavior, fisheries product 


\section{PENDAHULUAN}

Pemasaran digital merupakan sistem pemasaran dengan memanfaatkan jaringan internet. Saat ini pemasaran digital makin diminati seiring perkembangan revolusi industri 4.0, hal ini terlihat pada data survey terhadap responden yang memanfaatkan internet di Indonesia sebanyak 196,7 juta jiwa (APJII, 2019). Hal ini dikarenakan pemasaran digital mampu menyampaikan berbagai informasi lebih cepat dan efisien, menjangkau semua wilayah, hemat biaya dan memberi target pasar yang luas (Chandra, 2001, Adelaar, 2000, Alemu et al., 2019).

Propinsi DKI Jakarta merupakan salah satu daerah dengan pengguna internet yang cukup besar, yaitu mencapai 8,9 juta orang. Data tersebut didukung oleh potensi demografi DKI Jakarta yang memiliki jumlah penduduk sebanyak 10,5 juta jiwa dengan 71\% diantaranya berusia produktif 15-64 tahun (BPS, 2020). Hal tersebut senada dengan data pengguna media sosial di Indonesia pada tahun 2020 didominasi pada rentang usia 25-34 tahun (Annur, 2020).

Terkait dengan pemasaran digital, salah satu produk yang banyak dipasarkan secara digital atau online adalah produk makanan yang berbahan baku hasil perikanan, baik produk segar maupun dalam bentuk olahan. Pemasaran produk perikanan secara digital dapat meningkatkan efisiensi rantai distribusi dan memudahkan interaksi dengan konsumen, sehingga manfaatnya dapat dirasakan oleh nelayan maupun pelaku bisnis hasil perikanan (KKP, 2020a). Selain itu advertensi dan penjualan produk perikanan lebih optimal melalui pemasaran digital (Homaidi, 2017).

Besarnya peluang bisnis pemasaran digital produk perikanan di DKI Jakarta membuat pelaku usaha berupaya mengembangkan usahanya. Upaya pengembangan ini memerlukan kemampuan merancang segmentasi dan strategi pemasaran agar menarik minat konsumen. Hal ini dikarenakan keputusan akhir pembelian dipengaruhi oleh berbagai faktor, diantaranya persepsi, karakteristik, dan perilaku konsumen. Persepsi merupakan hasil dari pengolahan informasi yang merupakan pandangan konsumen terhadap pemasaran digital hasil perikanan. Ada tiga hal yang dapat mempengaruhi persepsi konsumen yaitu kondisi individu konsumen, dorongan dari sekelilingnya dan jenis dorongan yang mempengaruhi (Setiadi, 2010). Sedangkan perilaku pembelian digital adalah penggunaan jaringan internet dalam proses pembelian produk dan jasa (Liang dan Lai, 2002). Perilaku pembelian menurut Kotler (2000) terdiri dari lima tahapan, yaitu: rekognisi pada kebutuhan konsumen, penelusuran informasi, melakukan evaluasi berbagai alternatif keputusan, keputusan kosumen pada proses pembelian, dan perilaku konsumen setelah pembelian.

Permasalahan penelitian adalah belum adanya informasi yang lengkap terkait perilaku dan persepsi konsumen terhadap pemasaran digital produk perikanan di DKI Jakarta. Jika informasi tersebut tidak tersedia maka bisa jadi pelaku bisnis akan kesulitan dalam menetapkan segmentasi pasar, kualitas produk yang diinginkan konsumen dan strategi pemasaran yang tepat. Menurut Sajeev (2018), kesuksesan pelaku bisnis pemasaran digital ditunjang oleh kemampuan merancang strategi pemasaran. Penelitian sebelumnya terkait perilaku konsumen menunjukkan bahwa terdapat hubungan nyata antara karakteristik dan perilaku konsumen pemasaran ikan laut di pasar tradisional Pekanbaru Provinsi Riau (Ani, 2017). Selain itu, hasil penelitian Khoirinnisa et al. (2019) menyimpulkan bahwa faktor-faktor yang mempengaruhi perilaku konsumen produk olahan ikan kaki naga di sebuah industri perikanan di Kabupaten Bogor adalah kepuasan pembelian, kepercayaan, tampilan produk, popularitas, promosi, pengetahuan produk, rasa dan tekstur. Penelitian Siburian (2020) menunjukkan bahwa terdapat perbedaan pada perilaku konsumen dalam pembelian ikan segar di pasar tradisional dan pasar modern di kota Medan. Sedangkan untuk penelitian persepsi konsumen terhadap pemasaran digital produk perikanan di DKI Jakarta belum dilakukan. Pada penelitian ini tidak ditentukan jasa layanan digital ataupun market place tertentu sebagai objek penelitian, karena tujuan penelitian untuk mengidentifikasi perilaku konsumen terhadap pemasaran digital perikanan secara umum. Penelitian ini sangat bermanfaat bagi para pelaku pemasaran digital produk perikanan untuk meningkatkan kinerja perusahaan dan merancang strategi pemasaran berbasis kepuasan konsumen. Berdasarkan uraian tersebut maka penelitian ini dilakukan melalui pendekatan analisis indeks kinerja (Martilla dan James, 1977) dan kepuasan konsumen. Tujuan penelitian adalah mengidentifikasi perilaku konsumen dan mengukur persepsi konsumen terhadap pemasaran digital produk perikanan di DKI Jakarta. 


\section{METODE PENELITIAN}

Kegiatan penelitian dilaksanakan pada tanggal 14 Juli 2020 hingga 14 Agustus 2020. Metode penelitian adalah studi kasus dengan satuan kasus adalah persepsi konsumen pemasaran digital produk perikanan yang berlokasi di DKI Jakarta.

Penelitian dilaksanakan saat pemberlakuan regulasi pembatasan aktivitas masyarakat akibat pandemi Covid 19 di DKI Jakarta, sehingga pengumpulan data dilakukan secara online. Pengumpulan data melalui pengisian kuesioner yang disusun menggunakan aplikasi google form. Link google form yang berisikan kuesioner disebarkan melalui media sosial berupa whatsapp, twitter, facebook dan instagram.

Kuesioner disusun untuk tujuan pengukuran persepsi konsumen terhadap pemasaran digital hasil perikanan. Pengukuran persepsi konsumen menggunakan skala Likert dengan 4 skala mulai dari sangat tidak setuju (skala 1), tidak setuju (skala 2), setuju (skala 3) hingga sangat setuju (skala 4).

Populasi penelitian adalah masyarakat yang berdomisili di DKI Jakarta yang mengonsumsi hasil perikanan melalui pemasaran digital. Responden penelitian adalah konsumen yang berdomisili di DKI Jakarta, berusia 17 tahun ke atas dan minimal satu kali melakukan kegiatan transaksi pembelian hasil perikanan dari pemasaran digital dalam tiga bulan terakhir. Penentuan responden dilakukan dengan pendekatan accidental sampling, dimana sampel penelitian ini adalah konsumen pemasaran digital hasil perikanan yang secara kebetulan menemukan link tersebut pada media sosial dan dapat menjawab setiap pertanyaan pada kuesioner serta memenuhi kriteria.

Jumlah responden yang dijadikan sampel adalah 100 orang. Perhitungan tersebut berdasarkan pendapat Hair et al. (2010) bahwa jumlah minimum sampel untuk populasi yang tidak diketahui adalah lima hingga sepuluh kali dari jumlah item pernyataan yang akan dianalisis di dalam kuesioner. Pernyataan yang dianalisis dalam kuesioner adalah 18 pernyataan kinerja dan kepentingan masing-masing atribut dalam pengukuran persepsi konsumen, sehingga jumlah sampel yang diambil adalah minimal 90 orang. Rumus penentuan jumlah sampel yang diambil dalam penelitian ini adalah sebagai berikut:

$$
n=k \times 5
$$

Keterangan:

$\mathrm{n} \quad=$ Responden Sampel

$\mathrm{k} \quad=$ Pernyataan dalam penelitian

$5 \quad$ = Jumlah observasi minimum untuk setiap pernyataan yang dianalisis

Analisis data yang digunakan dalam penelitian ini: (1) Analisis deskriptif, (2) Important Performance Analysis (IPA) dan Customer Satisfaction Index (CSI).

\section{Analisis Deskrptif terhadap Perilaku Konsumen}

Analisis perilaku konsumen dalam pemasaran digital dilakukan secara deskriptif melalui pendekatan lima tahapan Kotler. Beberapa alasan yang dianalisis dalam perilaku konsumen tertera pada Tabel 1.

Tabel 1 Perilaku konsumen dalam pembelian produk perikanan secara digital

\begin{tabular}{lll}
\hline \multicolumn{1}{c}{ Tahapan } & & \multicolumn{1}{c}{ Alasan Konsumen } \\
\hline A. Kebutuhan & - & Sulit didapatkan dari pemasaran non-digital \\
& - & Harganya yang terjangkau \\
& - & Dapat memesan dalam jumlah dan ukuran yang diinginkan \\
& - & Praktis \\
B. Sumber informasi & - Mesin Pencarian (Website/Google) \\
& - Market Place (Shopee, Tokopedia, Lazada, dan lainnya) \\
& - Redia Sosial (WA, IG, Facebook, dan lainnya) \\
C. Evaluasi alternatif & - Harga \\
& - Tingkat kualitas \\
& - Baktu pengiriman \\
&
\end{tabular}




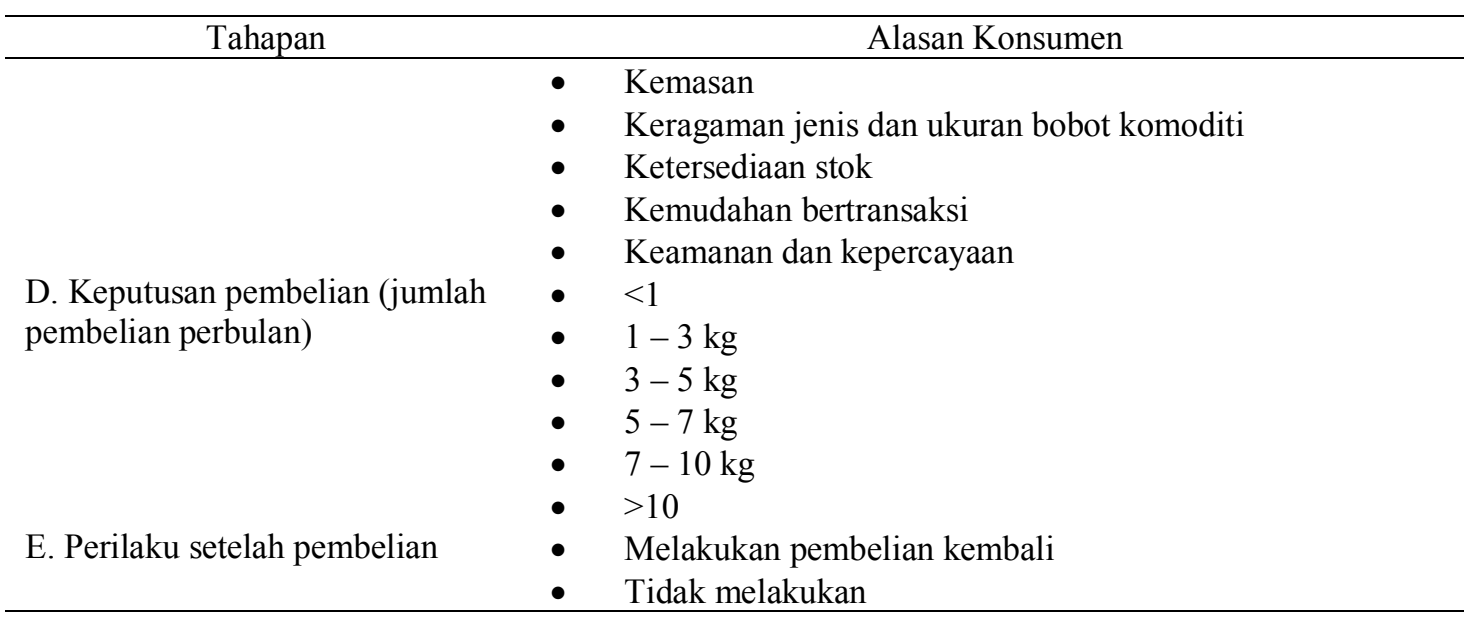

Sumber: Kotler (2000) yang telah dimodifikasi

\section{Important Performance Analysis dan Customer Satisfaction Index}

Analisis IPA dan CSI dilakukan melalui pengukuran persepsi konsumen terhadap proses pembelian produk perikanan melalui digital marketing. Dalam hal ini tidak ditentukan perusahaan yang dinilai karena konsumen menilai kinerja dari kegiatan pemasaran digital secara umum. Pentingnya mengukur persepsi konsumen adalah untuk mengetahui gambaran positif dan negatif hasil perikanan dari pemasaran digital. Tingkat pendapat konsumen diukur melalui empat opsi pilihan dalam kuesioner dimana masing masing opsi pilihan diberi rentang nilai 1-4. Skala Likert yang digunakan dalam penentuan persepsi konsumen tertera pada Tabel 2.

Tabel 2. Skala Likert dalam penentuan persepsi konsumen

\begin{tabular}{|c|c|}
\hline No & Parameter \\
\hline 1 & $\begin{array}{l}\text { Harga hasil perikanan dari pemasaran digital lebih terjangkau dibandingkan pemasaran non- } \\
\text { digital }\end{array}$ \\
\hline 2 & Hasil perikanan dari pemasaran digital memiliki tingkat kualitas yang baik \\
\hline 3 & $\begin{array}{l}\text { Pesanan hasil perikanan dari pemasaran digital selalu sampai sesuai waktu pengiriman yang } \\
\text { sudah disepakati }\end{array}$ \\
\hline 4 & Biaya pengiriman hasil perikanan dari pemasaran digital terjangkau \\
\hline 5 & $\begin{array}{l}\text { Hasil perikanan dari pemasaran digital dilengkapi dengan kemasan dan pengepakan yang } \\
\text { baik }\end{array}$ \\
\hline 6 & $\begin{array}{l}\text { Pemasaran digital memiliki keragaman jenis dan ukuran komoditi hasil perikanan yang } \\
\text { beragam }\end{array}$ \\
\hline 7 & Pemasaran digital memiliki ketersediaan stok hasil perikanan yang memadai \\
\hline 8 & Hasil perikanan dari pemasaran digital memberikan kemudahan dalam bertransaksi \\
\hline 9 & $\begin{array}{l}\text { Hasil perikanan dari pemasaran digital memiliki tingkat keamanan dan kepercayaan yang } \\
\text { tinggi }\end{array}$ \\
\hline
\end{tabular}

Sumber: pengamatan dan hasil wawancara

Penilaian persepsi konsumen didasarkan pada analisis kinerja pemasaran digital produk perikanan. Analisis ini bertujuan untuk mengetahui kepentingan dan kinerja masing-masing variabel dari faktorfaktor kepuasan konsumen. Tingkat kepentingan yang dimaksud adalah seberapa penting atribut pemasaran digital produk perikanan bagi konsumen atau seberapa besar harapan konsumen terhadap kinerja tersebut. Sedangkan tingkat kinerja adalah atribut yang secara aktual dirasakan konsumen. Hasil perhitungan berupa rata-rata bobot $(\bar{X})$ untuk kinerja dan rata- rata bobot $(\bar{Y})$ untuk kepentingan dihitung menggunakan rumus sebagai berikut:

$$
\begin{aligned}
& \bar{X}=\frac{\sum X_{i}}{n} \\
& \bar{Y}=\frac{\sum Y_{i}}{n}
\end{aligned}
$$

Keterangan:

$\bar{X}=$ Skor rata-rata tingkat kinerja; 
$\bar{Y} \quad=\quad$ Skor rata-rata tingkat kepentingan;

$\sum \mathrm{X}_{\mathrm{i}} \quad=$ Total skor tingkat kinerja dari seluruh konsumen;

$\sum \mathrm{Y}_{\mathrm{i}}=$ Total skor tingkat kepentingan dari seluruh konsumen; dan

$\mathrm{N} \mathrm{n}=$ Jumlah konsumen pemasaran digital hasil perikanan yaitu 100 konsumen.

Rumus yang digunakan untuk menyusun matriks IPA adalah sebagai berikut:

$$
\begin{aligned}
& \overline{\bar{X}}=\frac{\sum_{i=1}^{n} \bar{X}}{k} \\
& \overline{\bar{Y}}=\frac{\sum_{i=1}^{n} \bar{Y}}{k}
\end{aligned}
$$

Keterangan:

$\overline{\bar{X}} \quad=\quad$ Skor rata-rata tingkat kinerja seluruh atribut;

$\overline{\bar{Y}} \quad=$ Skor rata-rata tingkat kepentingan seluruh atribut;

$\bar{X} \quad=\quad$ Skor rata-rata tingkat kinerja atribut i;

$\bar{Y} \quad=$ Skor rata-rata tingkat kepentingan atribut $\mathrm{i}$;

$\mathrm{n} \quad=$ Jumlah konsumen (100); dan

$\mathrm{k}=$ Banyaknya atribut yang dapat mempengaruhi kepuasan konsumen yaitu 9 .

Matriks IPA diperlukan untuk penjabaran tingkat kinerja dan kepuasan konsumen. Pembagian kuadran dalam matriks IPA tertera pada Gambar 1.

$Y$ (Tingkat Kepentingan)

Tinggi

\begin{tabular}{l|c} 
Kuadran I \\
(Prioritas utama) & $\begin{array}{c}\text { Kuadran II } \\
\text { (Pertahankan prioritas) }\end{array}$ \\
\hline Kuadran III \\
(Prioritas rendah) & $\begin{array}{c}\text { Kuadran IV } \\
\text { (Prioritas rendah) }\end{array}$ \\
\hline
\end{tabular}

Gambar 1. Bentuk matriks Importance Performance Analysis (Martilla dan James, 1977)

Metode indeks kepuasan konsumen bertujuan untuk mengukur tingkat kepuasan konsumen. Rumus untuk menghitung indeks kepuasan berdasarkan Hill dan Alexander (2006), yaitu:

1. Menghitung rata-rata tingkat kepentingan dan kinerja tiap konsumen.

$$
\begin{aligned}
& M I S=\frac{\sum_{i=1}^{n} Y i}{n} \\
& M S S=\frac{\sum_{i=1}^{n} X i}{n}
\end{aligned}
$$

Keterangan:

MIS = Mean Importance Score

MSS $=$ Mean Satisfaction Score

$n \quad=$ Jumlah konsumen;

$\mathrm{Y}_{\mathrm{i}} \quad=\quad$ Nilai kepentingan atribut ke-i; dan

$\mathrm{X}_{\mathrm{i}} \quad=\quad$ Nilai kinerja atribut ke-i.

2. Menghitung Weight Factors (WF).

$$
W I F i=\frac{M I S i}{\sum_{i=1}^{p} \text { MISi }} \times 100 \%
$$


Keterangan:

$\begin{array}{ll}p & =\text { Jumlah atribut kepentingan; } \\ i & =\text { Atribut ke-i; dan } \\ \text { MISi } & =\text { Skor rata-rata kepentingan atribut ke-i. }\end{array}$

3. Menghitung Weight Score (WS)

$$
W S_{i}=W F_{i} x M S S_{i}
$$

Keterangan:

$i=$ Atribut aspek kemampuan kelompok ke-i;

$\mathrm{WF} \quad=$ Weighting Factors; dan

MSS = Skor rata-rata kinerja atribut ke-i.

4. Menghitung Indeks Kepuasan Konsumen

$$
C S i=\frac{\sum_{i=1}^{P} W S i}{H S} \times 100 \%
$$

Keterangan:

$$
\begin{array}{ll}
p & =\text { Atribut kepentingan ke-p; } \\
W S & =\text { Weight Score; dan } \\
H S & =\text { Highest Scale atau skala maksimum yang digunakan yaitu } 5 .
\end{array}
$$

Selanjutnya dibuat rentang skala untuk menjelaskan nilai indeks kepuasan konsumen berdasarkan rumus rentang skala Simamora (2004).

$$
R S=\frac{\mathrm{m}-\mathrm{n}}{\mathrm{b}}
$$

Keterangan:

$R S \quad=$ Rentang skala;

$\mathrm{m} \quad=$ Skor tertinggi;

$n \quad=\quad$ Skor terendah; dan

$\mathrm{b}=$ Jumlah kelas atau kategori yang akan dibuat (dalam penelitian ini digunakan skala maksimal 5).

Kepuasan tertinggi jika indeks kepuasan konsumen mencapai 100\%, sehingga rentang skalanya dapat dihitung sebagai berikut:

$$
R S=\frac{100 \%-0 \%}{5}=20 \%
$$
Tabel 3

Selanjutnya dibuat nilai indeks dan kriteria indeks kepuasan konsumen sebagaimana tertera pada

Tabel 3. Interpretasi angka indeks kepuasan konsumen

\begin{tabular}{ll}
\hline \multicolumn{1}{c}{ Nilai Indeks } & \multicolumn{1}{c}{ Kriteria Indeks Kepuasan } \\
\hline $80 \%<$ indeks kepuasan $\leq 100 \%$ & Sangat puas \\
$60 \%<$ indeks kepuasan $\leq 80 \%$ & Puas \\
$40 \%<$ indeks kepuasan $\leq 60 \%$ & Cukup puas \\
$20 \%<$ indeks kepuasan $\leq 40 \%$ & Kurang puas \\
$0 \%<$ indeks kepuasan $\leq 20 \%$ & Tidak puas \\
\hline
\end{tabular}

Sumber : Martilla dan James (1977) 


\section{HASIL DAN PEMBAHASAN}

\section{Karakteristik Konsumen}

Karakteristik konsumen hasil perikanan pada pemasaran digital dibedakan berdasarkan usia, pendidikan, pekerjaan, pendapatan per bulan, dan jenis kelamin (Tabel 4). Karakteristik inilah yang dapat memengaruhi perilaku proses pembelian. Oleh sebab itu, gambaran karakteristik konsumen diharapkan dapat menjadi sumber informasi untuk tujuan evaluasi dan penyusunan strategi pemasaran pelaku usaha hasil perikanan dari pemasaran digital.

Tabel 4. Karakteristik responden

\begin{tabular}{lclc}
\hline Kelompok usia (tahun) & Frekuensi & Jenis Pekerjaan & Frekuensi \\
\hline $17-21$ & 8 & Ibu Rumah Tangga & 26 \\
$22-26$ & 36 & Pelajar/Mahasiswa & 9 \\
$27-31$ & 32 & Pegawai Negeri & 7 \\
$32-36$ & 12 & Pegawai Swasta & 32 \\
$37-41$ & 5 & Profesional & 12 \\
$42-46$ & 3 & Wiraswasta & 14 \\
$47-51$ & 2 & Total & 100 \\
\cline { 2 - 4 } 52-56 & 2 & Pendapatan Per Bulan (Rp) & Frekuensi \\
Total & 100 & $<1.000 .000$ & 7 \\
\hline Tingkat pendidikan & Frekuensi & $1.000 .001-2.500 .000$ & 17 \\
\hline SD & 2 & $2.500 .001-5.000 .000$ & 37 \\
SMP & 2 & $5.000 .001-10.000 .000$ & 30 \\
SMA/SMK & 33 & $>10,000.000$ & 9 \\
Diploma & 12 & Total & 100 \\
Sarjana & 44 & Jenis kelamin & Frekuensi \\
Pasca-sarjana & 7 & Perempuan & 20 \\
Total & 100 & Laki-laki & 100 \\
& & Total & \\
\hline
\end{tabular}

Sumber: hasil analisis

Tabel 4 menunjukkan bahwa karakteristik responden konsumen sangat beragam, untuk usia didominasi rentang usia 22-26 tahun (36\%) yang merupakan usia produktif dan banyak menggunakan internet. Karakteristik tingkat pendidikan didominasi tingkat Sarjana (44\%) dengan karakteristik pekerjaan responden didominasi oleh karir sebagai pegawai swasta (32\%). Kelompok pekerjaan mempengaruhi kecenderungan seseorang dalam melakukan pembelian terhadap produk tertentu. Seperti contohnya kelompok profesional dapat memiliki motif yang berbeda dengan wiraswasta dalam hal membeli hasil perikanan dari pemasaran digital, Karakteristik pendapatan responden perbulan Rp2,5-5 juta menunjukkan responden pada pendapatan menengah ke bawah, hal ini dapat dipahami karena usia responden masih tergolong muda dan baru memulai karir. Tingkat pendapatan membentuk pola konsumsi, gaya hidup, dan meningkatkan daya beli seseorang (Ramya dan Ali, 2016). Karakteristik jenis kelamin responden didominasi oleh gender perempuan (80\%), hal ini menunjukkan peran domestik yang harus dijalani oleh seorang perempuan untuk mengurus kerumahtanggaan seperti memasak dan berbelanja kebutuhan rumah tangga (Putri dan Lestari, 2015).

\section{Perilaku Konsumen dalam Pembelian Produk Perikanan}

Perilaku konsumen yang ditunjukkan pada alasan kebutuhan membeli produk perikanan melalui pemasaran digital didominasi oleh alasan praktis (60\%). Hal ini dapat dipahami karena pembelian digital menawarkan kepraktisan berupa tidak perlu keluar biaya transportasi, tidak perlu keluar rumah, berdesakdesakan di tempat pembelanjaan, terjebak dalam antrian, cepat diterima, menghemat waktu, serta dapat diakses di mana pun dan kapan pun (Lestari, 2015). Ditambah lagi pemasaran digital menjadi alternatif bagi sebagian besar masyarakat ketika diberlakukan pembatasan sosial pada saat pandemi Covid 19. Hasil analisis proses perilaku pembelian produk perikanan disajikan pada Tabel 5. 
Tabel 5. Hasil analisis proses perilaku pembelian produk perikanan

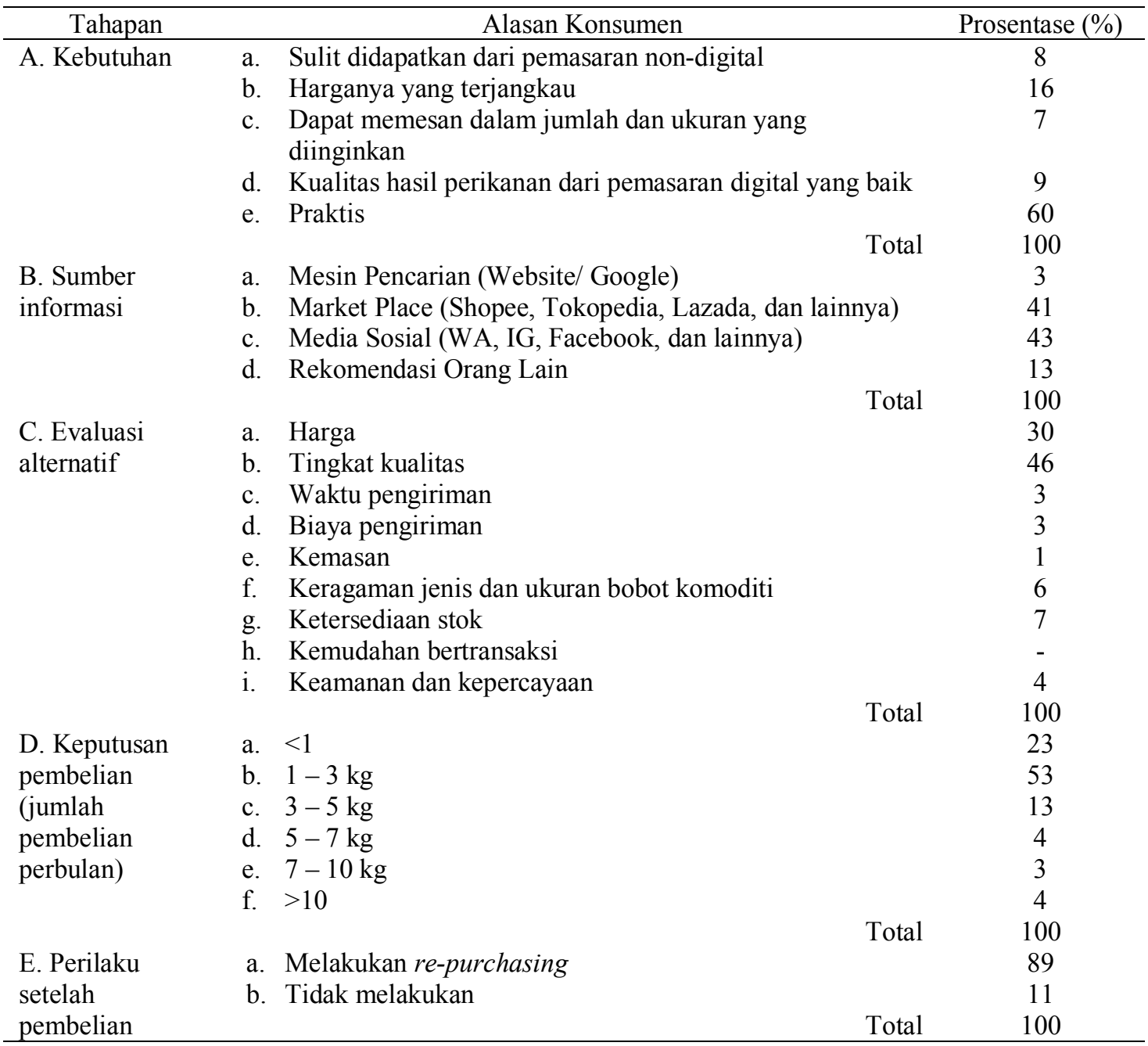

Sumber: hasil analisis

Selanjutnya perilaku konsumen terkait sumber informasi yang banyak digunakan adalah media sosial mencapai $43 \%$ disusul dengan market place $41 \%$. Media sosial dalam peranannya memiliki kelebihan berupa pesan yang disampaikan dapat dibagikan ke banyak orang, lebih cepat sampai dan fleksibel dalam waktu interaksi (Baktiono dan Artaya, 2016). Selain itu, media sosial dinilai sebagai platform termurah dan terbaik dalam memajukan bisnis tanpa menghabiskan banyak uang untuk situs web dan iklan yang mahal (Sajeev, 2018). Tingginya pengguna media sosial juga menjadi kelebihan dalam penyebaran info penjualan. Cukup dengan memasang status pada media sosial, informasi produk akan tersebar. Media sosial yang seringkali digunakan adalah facebook, instagram dan twitter (APJII, 2020).

Perilaku konsumen terkait dengan alasan membeli produk perikanan melalui pemasaran digital adalah terkait dengan kualitas (46\%). Tabel 5 menunjukkan tingginya kesadaran masyarakat akan pentingnya kualitas hasil perikanan di atas atribut harga dan atribut lainnya. Menurut Freitas et al. (2019), kualitas hasil perikanan dapat dilihat dari empat pilar, yaitu freshness, safety, traceability dan authenticity. Selain itu, sebanyak 36\% konsumen memiliki alasan harga dalam menentukan pembelian produk perikanan melalui pemasaran digital.

Perilaku konsumen terkait dengan keputusan pembelian, sebagian besar responden menyatakan membeli produk perikanan secara digital rata-rata $1-3 \mathrm{~kg} /$ bulan atau sekitar $12-36 \mathrm{~kg} /$ tahun. Data konsumsi ikan per kapita per tahun di DKI Jakarta yaitu 25,40 kg/kapita/tahun sedangkan konsumsi ikan nasional sebanyak 56,39 kg/kapita per tahun (KKP, 2020b). Dalam hal kebiasaan, masyarakat Indonesia memiliki kendala dalam mengkonsumsi ikan berupa; rasa bosan yang timbul jika dikonsumsi secara terus menerus, alergi, bau amis, dan harganya yang mahal (Ernawati, 2017). Oleh sebab itu, mayoritas masyarakat Indonesia memilih barang substitusi sebagai sumber protein hewani selain ikan yang dinilai 
lebih praktis, mudah dimasak, memenuhi selera saat dikonsumsi, enak, dan terjangkau seperti telur dan ayam (Ariani et al., 2018). Variasi dalam mengkonsumsi makanan ikan dapat juga dipengaruhi oleh beberapa faktor seperti aspek sosial ekonomi, demografi, letak geografis dan kebiasaan makan (Aydin et al., 2011, Ahmad et al., 2016).

Perilaku konsumen setelah pembelian, sebanyak $89 \%$ menyatakan akan melakukan repurchasing produk perikanan secara online. Salim et al. (2018) menyatakan bahwa mayoritas alasan konsumen melakukan pembelian digital hasil perikanan karena menghemat waktu, adanya kesiapan produk, kualitas, ketersediaan, aksesibilitas, dan keterjangkauan. Keputusan untuk melakukan pembelian kembali secara digital karena pelanggan mendapatkan keuntungan ketika membeli barang dari toko online dibandingkan dengan pembelian secara konvensional di toko offline (Karayanni, 2003).

\section{Analisis Persepsi Terhadap Pemasaran Digital Hasil Perikanan}

\section{Important Performance Analysis (IPA)}

Pengukuran dengan menggunakan IPA dapat menunjukkan atribut apa saja yang mempengaruhi kepuasan konsumen. Penilaian rata-rata nilai kinerja dan kepentingan IPA tertera pada Tabel 6 .

Tabel 6 Penilaian rata-rata nilai kinerja dan kepentingan IPA

\begin{tabular}{clcc}
\hline No & \multicolumn{1}{c}{ Atribut } & Rataan Kinerja & Rataan Kepentingan \\
\hline 1 & Harga & 2,64 & 3,44 \\
2 & Tingkat kualitas & 2,72 & 3,47 \\
3 & Waktu pengiriman & 3,00 & 3,32 \\
4 & Biaya pengiriman & 2,72 & 3,24 \\
5 & Kemasan dan pengepakan & 3,10 & 3,52 \\
6 & Keragaman jenis dan ukuran komoditi & 3,13 & 3,27 \\
7 & Ketersediaan stok & 3,08 & 3,25 \\
8 & Kemudahan bertransaksi & 3,39 & 3,44 \\
9 & Tingkat kepercayaan dan keamanan & 3,11 & 3,38 \\
& $\quad$ Total & 26,89 & 30,33 \\
& Rata-rata $(\bar{X}, \bar{Y})$ & 2.99 & 3.37 \\
\hline
\end{tabular}

Sumber: hasil analisis

Perbandingan rata-rata nilai kinerja dan kepentingan digambarkan melalui matriks IPA. Matriks IPA memuat atribut yang tersebar dalam empat kuadran sebagai bahan evaluasi apakah sebuah atribut tersebut perlu ditingkatkan atau belum perlu diprioritaskan untuk ditingkatkan (sudah baik). Gambar 2 merupakan tampilan dari matriks IPA untuk penilaian terhadap hasil perikanan dari pemasaran digital.

Berdasarkan perhitungan maka diperoleh $X=2,99$ dan $Y=3,37$. Berikut analisis terhadap empat kuadran pada matriks IPA pemasaran digital hasil perikanan:

1. Kuadran I (Prioritas Utama)

Kuadaran ini menjelaskan bahwa atribut harga dan kualitas memiliki tingkat kepentingan yang tinggi dengan tingkat kinerja yang rendah. Oleh sebab itu, pelaku usaha hasil perikanan dari pemasaran digital perlu memprioritaskan perbaikan pada kinerja harga dan kualitas produk perikanan. Atribut harga memiliki keterkaitan erat dengan daya beli konsumen. Hal ini dikarenakan penilaian konsumen terhadap harga barang dipengaruhi oleh kesesuaian antara pengorbanan yang dikeluarkan dengan nilai yang didapatkan konsumen (Kertajaya, 2002). Ketika konsumen merasakan kepuasan terhadap proses pembelian produk perikanan secara digital, maka akan muncul persepsi positif, dan sebaliknya ketika ada ketidakpuasan maka akan muncul persepsi yang negatif.

2. Kuadran II (Pertahankan Prestasi)

Kuadran II menjelaskan bahwa atribut kemasan produk, kemudahan bertransaksi, serta kepercayaan dan keamanan pemasaran digital produk perikanan memiliki nilai kepentingan dan tingkat kinerjanya yang tinggi. Hal ini perlu dipertahankan agar kepuasan konsumen pada variabel tersebut tidak menurun. 
Persepsi kemasan mengacu pada persepsi tiap individu terhadap kemasan dan pengepakan yang dilakukan oleh pelaku usaha hasil perikanan untuk mempertahankan kualitas produknya. Kemasan memiliki arti semua bentuk pengemasan dan prosesnya yang digunakan untuk membungkus suatu produk (Kuspriyono, 2017). Kemasan hasil perikanan dari pemasaran digital memiliki fungsi memberi kemudahan dalam proses penggunaan (operating), distribusi (shipping), serta pelindung (protection) untuk menjaga dan mempertahankan kualitas hasil perikanan dari penjual ke tangan konsumen selama waktu pengiriman. Pelaku usaha perlu memastikan pemenuhan ketiga fungsi tersebut selama mengemas hasil perikanan untuk mempertahankan kinerja atribut kemasan.

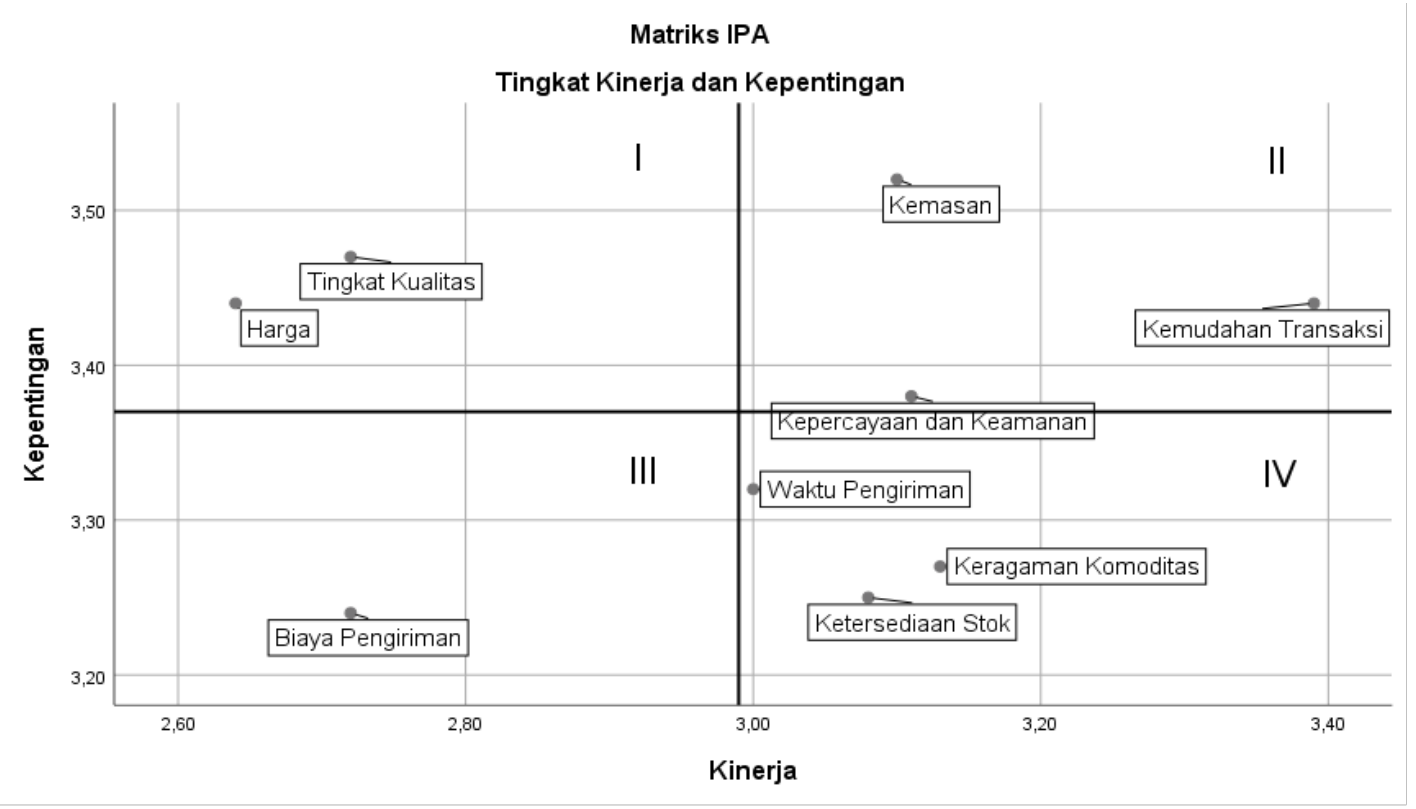

Gambar 2 Matriks IPA atribut hasil perikanan dari pemasaran digital

3. Kuadran III (Prioritas Rendah)

Kuadran III menjelaskan bahwa biaya pengiriman merupakan atribut yang kepentingannya dianggap rendah oleh konsumen serta kinerja yang diberikan juga masih rendah. Atribut yang berada di kuadran III yaitu atribut biaya pengiriman. Biaya pengiriman belum perlu melakukan perbaikan. Persepsi biaya pengiriman mengacu pada persepsi individu terhadap harga yang harus dibayarkan kepada jasa pengiriman atas jasanya mengirimkan hasil perikanan yang dibeli secara online. Biaya pengiriman sangat beragam tarifnya. Keberagamanan tarif dipengaruhi oleh kebijakan masingmasing perusahaan jasa pengiriman, keterjangkauan lokasi, kecepatan pengiriman, kendaraan yang digunakan, jaminan produk, dan pelayanan (Anandhita, 2014). Pelaku usaha dapat bekerja sama dengan banyak jasa pengiriman sehingga konsumen dapat memilih biaya pengiriman yang terjangkau dari masing-masing jasa pengiriman untuk mempertahankan kinerja atibut biaya pengiriman.

4. Kuadran IV (Berlebihan)

Kuadaran IV menjelaskan bahwa atribut waktu pengiriman, keragaman komoditas, dan atribut ketersediaan stok adalah atribut yang kurang penting menurut konsumen, namun apa yang dilakukan pelaku usaha terkait dengan atribut tersebut dirasa sangat baik. Pelaku usaha tidak perlu terlalu fokus terhadap peningkatan kinerja atribut tersebut, karena nilai kinerja atribut tersebut yang sudah baik.

Keanekaragaman komoditi dan ukuran mengacu pada persepsi tiap individu terhadap beragamnya komoditi lengkap beserta ukuran yang ditawarkan pelaku usaha pemasaran digital hasil perikanan. Menurut $\mathrm{Wu}$ et al. (2019) semakin banyak pilihan yang dimiliki konsumen, semakin banyak pula penguasaan diri sehingga membuat konsumen lebih memperhatikan keinginan dan kepuasan batin mereka. Semakin banyak pilihan yang ditawarkan pelaku usaha kepada konsumen, semakin sensitif kebutuhan konsumen, dan semakin puas dalam memilih (Kahn dan Wansink, 2004). Konsumen dapat membeli lebih dari satu komoditi yang disukai dengan selera ukuran masing-masing tanpa perlu mengeluarkan ongkos kirim beberapa kali. Pelaku usaha perlu menjaga ketersediaan aneka komoditi dan ukuran hasil perikanan sehigga dapat mempertahankan persepsi positif konsumen. 


\section{Customer Satisfaction Index (CSI)}

Penilaian rata-rata nilai kinerja dan kepentingan CSI disajikan pada Tabel 7.

Tabel 7 Penilaian rata-rata nilai kinerja dan kepentingan CSI

\begin{tabular}{llcccc}
\hline No & \multicolumn{1}{c}{ Atribut } & $\begin{array}{c}\text { Rata-rata } \\
\text { Kinerja }\end{array}$ & $\begin{array}{c}\text { Rata-rata } \\
\text { Kepentingan }\end{array}$ & WF & WS \\
\hline 1 & Harga & 2,64 & 3,44 & 0,09 & 0,34 \\
2 & Tingkat kualitas & 2,72 & 3,47 & 0,10 & 0,35 \\
3 & Waktu pengiriman & 3,00 & 3,32 & 0,11 & 0,37 \\
4 & Biaya pengiriman & 2,72 & 3,24 & 0,10 & 0,33 \\
5 & Kemasan dan pengepakan & 3,13 & 3,52 & 0,12 & 0,41 \\
6 & Keragaman jenis dan ukuran komoditi hasil & 3,08 & 3,27 & 0,12 & 0,38 \\
& perikanan & & & & \\
7 & Ketersediaan stok yang memadai & 3,10 & 3,25 & 0,11 & 0,37 \\
8 & Kemudahan bertransaksi & 3,39 & 3,44 & 0,13 & 0,43 \\
9 & Kepercayaan dan keamanan & 3,11 & 3,38 & 0,12 & 0,39 \\
& $\quad$ Total \\
\multicolumn{2}{c}{ CSI } & 26,89 & 30,33 & 1.00 & 3.37 \\
& $\quad$ & $67 \%$ & & \\
\hline
\end{tabular}

Keterangan: WF $=$ Weight Factors; WS $=$ Weight Score

Sumber : hasil analisis

Berdasarkan hasil perhitungan indeks kepuasaan konsumen terhadap pemasaran hasil perikanan secara digital didapat nilai sebesar 0,67 atau $67 \%$. Nilai tersebut terdapat pada rentang skala $0,60-0,80$ (artinya konsumen puas). Berdasarkan hal tersebut, masih terdapat 33\% atribut kinerja yang belum memenuhi kepuasan konsumen. Tingkat kepuasan ini merupakan perhitungan dari hasil wawancara terhadap konsumen sampel penelitian, sehingga tingkat kepuasan dapat memiliki nilai yang berbeda jika konsumennya berubah. Tingkat kepuasan juga menjadi landasan pentingnya pelaku usaha digital hasil perikanan untuk terus meningkatkan kinerjanya pada taraf kepuasan konsumen $100 \%$.

\section{KESIMPULAN DAN SARAN}

Perilaku konsumen dalam pemasaran digital produk perikanan adalah sebagai berikut: konsumen membeli produk perikanan melalui pemasaran digital dengan alasan praktis $(60 \%)$, sumber informasi pembelian dari media sosial (43\%), konsumen memperhatikan tingkat kualitas (46\%), konsumen membeli rata-rata $1-3 \mathrm{~kg}$ produk perikanan (53\%) dan konsumen melakukan pembelian kembali (89\%). Persepsi konsumen terhadap keseluruhan atribut pemasaran digital hasil perikanan adalah puas (67\%), dengan prioritas utama peningkatan kinerja terletak pada atribut harga dan kualitas hasil perikanan dari pemasaran digital.

Saran dari penelitian ini adalah pelaku usaha hasil perikanan perlu meningkatkan kinerjanya pada atribut harga dan kualitas. Survei kepuasan konsumen dan upaya promosi produk perikanan perlu dilakukan secara periodik guna meningkatkan pelayanan dan tingkat konsumsi ikan.

\section{DAFTAR PUSTAKA}

Adelaar T. 2000. Electronic commerce and implifications for market structure: the example of the art and antiques trade. J of Comp Med Comm. 5 (3).

Ahmad NI, Rozita W, Mahiyuddin W, Tengku TR, Ling CY, Daud SF, Hussen NC, Abdullah NA, Shaharudin R, Sulaiman LH. 2016. Fish consumption pattern among adults of different ethnics in Peninsular Malaysia. Food Nut Res. 1:1-15.

Alemu MH, Sigurdsson V, Fagerstorm A, Foxall GR. 2019. Developing the e-commerce sector for the fishery industry: what bussines are we really in?. Manag Decis Econ. 1-17.

Anandhita VH. 2014. Studi pemilihan layanan jasa pengiriman oleh pelaku bisnis online sebagai sarana distribusi produk menggunakan strategi marketing mix di DKI Jakarta. Jurnal Penelitian Pos dan Informatika. 3(1): 1-18.

Ani NR. 2017. Analisis Perilaku Konsumen Ikan Laut Di Pasar Tradisional Arengka Kota Pekanbaru 
Provinsi Riau [skripsi]. Universitas Riau, Pekanbaru

Annur CM. 2020. Pengguna Media Sosial di Indonesia Berdasarkan Umur \& Gender. Katadata.co.id Diakses pada: https://databoks.katadata.co.id/datapublish/2020/11/23/berapa-usia-mayoritaspengguna-media-sosial-di-indonesia. [Diunduh 04 Juli 2021].

Ariani M, Suryana A, Suhartini SH, Saliem HP. 2018. Keragaan konsumsi pangan hewani berdasarkan wilayah dan pendapatan di tingkat rumah tangga. AKP. 16(2): 147-163.

Asosiasi Penyelenggara Jasa Internet Indonesia (APJII). 2020. Survei pengguna internet APJII 2019-Q2 2020, Bul APJII Ed 78. 1-2.

Aydin H, Dileh MK, Aydin K. 2011. Trends in fish and fishery product concumption in Turkey. TR J Fish Aqua Sc. 11: 499-506.

Baktiono RA dan Artaya IP. 2016. Memilih media sosial sebagai sarana bisnis online melalui pendekatan uji categorical. J Man Kin. 2: 2.

Badan Pusat Statistik Indonesia (BPS). 2020, Survei Jumlah Penduduk 2019. Jakarta (ID): Badan Pusat Statistik Jakarta.

Chandra G. 2001. Pemasaran Global. Ed ke-1. Yogyakarta (ID): Penerbit Andi.

Ernawati P. 2017. Analisis tingkat konsumsi ikan pada Masyarakat Kawasan Minapolitan, Kecamatan Wajak, Kabupaten Malang, Jawa Timur [skripsi]. Universitas Brawijaya, Malang.

Freitas J, Vaz-Pires P, Camara JS. 2019. From aquaculture production to consumption: Freshness, safety, traceability and authentication, the four pillars of quality, Aquac. 1-53.

Hair JF, Black WC, Babin BJ, Anderson RO. 2010. Multivariate Data Analysis. 7th Ed. New Jersey(NJ): Prentice Hall.

Homaidi A. 2017. Analisis perancangan e-commerce untuk pemasaran olahan hasil perikanan. AiTech. $3(1): 1-8$.

Karayanni DA. 2003. Webshoppers and nonshoppers: compatibility, relative advantage and demographics. Eu Bus Rev.15(3): 141-152

Kahn BE, Wansink B. 2004. The influence of assortment structure on perceived variety and consumption quantities. J Cons Res. 30: 519-533.

Kertajaya H. 2002. Marketing Plus Siasat Memenangkan Persaingan Global. Jakarta (ID): PT. Erlangga

Kementerian Kelautan dan Perikanan (KKP). 2017. Kelautan dan Perikanan dalam Angka tahun 2017. Kementerian Kelautan dan Perikanan Republik Indonesia.

Kementerian Kelautan dan Perikanan (KKP). 2020a, Mendorong pelaku UMKM melek teknologi dengan pengembangan digital marketing. Diakses pada: https://kkp.go.id/brsdm/artikel/25108-kkpdorong-pelaku-umkm-kp-melek-teknologi . \{Diunduh 04 Juli 2021\}.

Kementerian Kelautan dan Perikanan (KKP). 2020b. Laporan Kinerja KKP tahun 2020.

Khoirinnisa E, Gumilar I, Nurhayati A. 2019. Analisis Perilaku Konsumen Dalam Keputusan Pembelian Produk Kaki Naga (Studi Kasus di CV. Bening Jati Anugrah, Kabupaten Bogor). Jurnal Perikanan Kelautan. 7 (1): 66-74.

Kotler P. 2000. Marketing Management. Edisi Milenium. Jersey (UK): Prentice Hall Intl Inc New.

Kuspriyono T. 2017. Pengaruh promosi online dan kemasan terhadap keputusan pembelian kosmetik merek Sariayu Martha Tilaar. J Perspektif. XV(2): 147-154.

Lestari SB. 2015. Shopping online sebagai gaya hidup. JIS. 14(2):24-41.

Liang TP, Lai HJ. 2002. Effect of store design on consumer purchases: An empirical study of on-line bookstores. Info Man. 39(6): 431-444.

Martilla JA, James JC. 1977. Importance performance analysis. J Mark. 41(1): 77-79. 
Putri DPK, Lestari S. 2015. Pembagian Peran Dalam Rumah Tangga Pada Pasangan Suami Istri Jawa. $J$ Pen Human. 16(1): 72-85.

Ramya N, Ali M. 2016. Factors Affecting Consumers Buying Behaviour. Inter J App Res. 2(10): 76-80,

Sajeev MV. 2018. E-marketing of fish: Scope and Dynamics. In: Extension Management Techniques for Up-scaling Technology Dissemination in Fisheries (emanual), Suresh A, Sajeev MV, Rejula K, Mohanty, AK (Eds.). India(IN) : Central Institute of Fisheries Technology.

Salim SS, James HE, Athira NR, Smitha RX, Shinu AM, Meharoof M. 2018. Assessment of Online Fish Marketing in Ernakulam District, Kerala. Asian J Agr Ext Econ Soc. 27(1):1-8.

Setiadi NJ. 2010. Perilaku Konsumen: Konsep dan Implikasi untuk Strategi dan Penelitian Pemasaran. Jakarta (ID): Kencana Media.

Siburian EA. 2020. Analisis Perilaku Konsumen Dalam Pembelian Ikan Segar Di Pasar Tradisional Dan Pasar Modern (Studi Kasus: Kecamatan Medan Sunggal, Kota Medan) [Tesis]. Universitas Sumatera Utara, Medan.

Simamora B. 2004. Panduan Riset Perilaku Konsumen. Jakarta : PT. Gramedia Pustaka Utama.

Solomon M. 1992. Consumer Behaviour: Buying, Having, and Being. Boston US: Allyn and Bacon.

$\mathrm{Wu}$ Y, Chen H, Wang H. 2019. The influence of product diversity on consumers' impulsive purchase in online shopping environment. US J Ind Bus Man. 680-698. 